\title{
FURTHER DISENTANGLING OF A TAXONOMIC PUZZLE: MAXILLARIA RAMOSA, ORNITHIDIUM PENDULUM, AND A NEW SPECIES, O. ELIANAE (ORCHIDACEAE)
}

\author{
Mario A. Blanco, ${ }^{1,2}$ Germán Carnevali, ${ }^{3}$ Diego Bogarín, ${ }^{2,4}$ \\ AND RODRIGO B. SINGER ${ }^{5}$
}

\begin{abstract}
McIllmurray and Oakeley (2004) demonstrated that the name Maxillaria ramosa has been misapplied to Ornithidium pendulum since 1967, and possibly corresponds to M. cassapensis. We refer Ornithidium ochraceum, $O$. loefgrenii, and Maxillaria spathulata to the synonymy of $O$. pendulum (in addition to the already recognized synonyms $O$. dichotomum and Scaphyglottis tafallae), and designate a lectotype for $O$. dichotomum. A new species from Venezuela and the Guianas (Ornithidium elianae), previously confused with $O$.pendulum, is described. An updated description of $O$. pendulum is presented along with a review of its complicated taxonomic history and the first record of this species for Costa Rica.
\end{abstract}

Resumen. McIllmurray y Oakeley (2004) demostraron que el nombre Maxillaria ramosa ha sido mal aplicado a Ornithidium pendulum desde 1967, y posiblemente corresponde a M. cassapensis. Referimos los nombres Ornithidium ochraceum, O. loefgrenii y Maxillaria spathulata a la sinonimia de $O$. pendulum (además de los sinónimos ya reconocidos $O$. dichotomum y Scaphyglottis tafallae), y designamos un lectotipo para $O$. dichotomum. Se describe una nueva especie de Venezuela y las Guyanas (O. elianae), la cual hasta ahora había sido confundida con $O$. pendulum. Se presenta una descripción actualizada de $O$. pendulum, una revisión de su complicada historia taxonómica, y el primer informe de esta especie para Costa Rica.

Keywords: Cymbidieae, Maxillaria, Maxillariinae, Ornithidium

Few orchid species have experienced such a complicated taxonomic history as Ornithidium pendulum (Poepp. \& Endl.) Cogn. (Fig. 1). This species has been described under six different names from three (or four) countries. It has been known by a misapplied name (Maxillaria ramosa Ruiz \& Pav.) for over 40 years, and it has been confused with a hitherto undescribed species from Venezuela and the Guianas. McIllmurray and Oakeley (2004) unraveled much of the confusion, but their paper has remained relatively unknown among orchid taxonomists. The present paper aims to further clarify the identity of $O$.pendulum.

Inês Cordeiro (SP), Phil Cribb and Clare Drinkell (K), Mar González Bausá (MA), Jonathan Gregson (BM), Jennifer Gruhn (MO), Eric Hágsater and Miguel Angel Soto Arenas (AMO), Muriel Hecquet and Fred Stauffer (G), Wesley Higgins (SEL), Henry Kesner and Gustavo A. Romero-González (AMES, GH), Mayra Maldonado and Margaret Dix (UVAL), Eliana Noguera (VEN), Gerardo Salazar (MEXU), Roberto Vásquez (Herbarium Vasquezianum, Bolivia), and Bruno Wallnöfer (W) kindly provided images and assistance from their respective herbaria. We thank the curators and staff of BM, CAR, CR, K, G, INB, M, MA, MO, MY, P, PAN, PORT, QCA, QCNE, SEL, SP, RENZ, USJ, W, WU, VEN, and Z, for assistance during our visits. Robert Dressler (Jardín Botánico Lankester, Universidad de Costa Rica), Samantha Koehler (Escola Superior de Agricultura Luiz de Queiroz, Universidade de São Paulo), and Norris Williams (FLAS) provided useful comments and corrections on a preliminary version of this manuscript. Adam Karremans (Jardín Botánico Lankester) collected the first record of Ornithidium pendulum in Costa Rica, which precipitated this study. Funding was provided by a Furniss Foundation graduate student fellowship from the American Orchid Society and a Kew Latin American Research Fellowship (Royal Botanic Gardens, Kew) to M. A. Blanco for work in European herbaria; by CICY to G. Carnevali for the project "Orchidaceae Neotropicales"; by the Darwin Initiative, UK, to D. Bogarín for the project "Conservation and Monitoring of Meso-American Orchids" (Ref. 14001); by FAPESP to R. B. Singer for postdoctoral work (process No. 01/08958-1); and by the U.S. National Science Foundation to Norris H. Williams and W. Mark Whitten (FLAS) for the project "Systematics of Maxillariinae (Orchidaceae): Generic delimitation, pollinator rewards, and pollination" (grant no. DEB-0234064).

${ }^{1}$ Department of Botany, University of Florida, 220 Bartram Hall, Gainesville, Florida 32611-8526, U.S.A. Email: mablanco@ufl.edu.Author for correspondence.

${ }^{2}$ Jardín Botánico Lankester, Universidad de Costa Rica, P. O. Box 1031-7050, Cartago, Costa Rica.

${ }^{3}$ Herbarium CICY, Centro de Investigación Científica de Yucatán, A. C., Calle 43, No. 130, Col. Chuburná de Hidalgo, Mérida 97200, Yucatán, México.

${ }^{4}$ Centro de Investigación en Orquídeas de los Andes “Ángel Andreetta,” Universidad Alfredo Pérez Guerrero, Extensión Gualaceo, Ecuador.

${ }^{5}$ Departamento de Botânica, Instituto de Biociências, Universidade Federal do Rio Grande do Sul, Av. Bento Gonçalves 9500, Bloco IV Prédio 43432 Sala 207, Bairro Agronomia, CEP 91501-970, Porto Alegre, RS, Brazil. 
Species of Ornithidium Salisb. ex R. Br. have until recently, been considered part of Maxillaria Ruiz \& Pav. by many authors (e.g., Foldats, 1970; Pabst and Dungs, 1977; Dunsterville and Garay, 1979; Ortiz, 1988, 1995; Sprunger et al., 1996; Atwood, 1999, 2003a; Romero and Carnevali, 2000; Hamer, 2001; Christenson, 2002a, 2002b; Dodson,
2002; Carnevali and Ramírez-Morillo, 2003; Govaerts et al., 2005). However, new phylogenetic analyses based on molecular data indicate that Maxillaria is grossly polyphyletic (Whitten et al., 2007), and we have segregated and reinstalled several genera within subtribe Maxillariinae, including Ornithidium (Blanco et al., 2007).

\section{TAXONOMIC History of ORNITHIDIUM PENDULUM AND ITS SYNONYMS}

Table 1 provides a summary of the major historical events in the taxonomy of $O$. pendulum, including its multiple synonyms, misapplied names, and species it has been confused with. Details for each basionym are provided below.

\section{Scaphyglottis pendula Poepp. \& Endl.}

This species was first described by Poeppig and Endlicher in 1836, from a plant collected in 1830 in Peru by Poeppig himself. They proposed the genus Scaphyglottis in the same publication (Poeppig and Endlicher, 1836), but most species assigned to that genus by Poeppig and Endlicher are currently placed in Fernandezia Ruiz \& Pav. 6

Bentham (1881: 325) suggested that Scaphyglottis pendula should be placed in Ornithidium, a genus created in 1813 by Robert Brown, and typified by Epidendrum coccineum Jacq. In 1904, Cogniaux formally transferred Scaphyglottis pendula to Ornithidium. Both Bentham and Cogniaux were correct: $O$. pendulum is indeed closely related to $O$. coccineum (Whitten et al., 2007). In 1945, Schweinfurth transferred the species to Maxillaria, in line with the inclusive circumscription of the latter genus prevalent at the time.

Hoehne (1953: 338), not having seen the type of Scaphyglottis pendula, suggested that this species (as Maxillaria pendula) could be closely related to Pseudomaxillaria chloroleuca (Barb. Rodr.) Hoehne (a synonym of Maxillaria parviflora (Poepp. \& Endl.) Garay 7). Brieger (1977), who never saw the type of $S$. pendula either, was probably misled by Hoehne's opinion and assigned Ornithidium anceps Rchb.f. (a synonym of Camaridium anceps (Rchb.f.) M. A. Blanco, a close relative of $M$. parviflora; see Atwood, 1993, 1999) to the synonymy of $S$. pendula, and transferred the latter to the genus Pseudomaxillaria Hoehne (typified by $P$. chloroleuca). The type of Scaphyglottis pendula is very different from those of P. chloroleuca and $O$. anceps; both Hoehne and Brieger relied exclusively on the inadequate original description and drawing of $S$. pendula to reach their conclusions. Brieger's (1977) assertion that "no other specimen of [Pseudomaxillaria pendula] has been found in Peru during the last 150 years" is clearly based on his erroneous synonymization.

The two known extant duplicates of the type collection of Scaphyglottis pendula are in the Naturhistorisches Museum in Vienna: W-Reich.Orch. No. 40118, which has only two leaves and two drawings of the plant; and W-0007400, which consists of a large specimen in good condition and was not part of the Reichenbach f. herbarium eventually bequeathed to $\mathrm{W}$, but must have been part of Poeppig's personal herbarium. Despite an exhaustive search, no duplicates were found in G, which holds many Poeppig collections.

The name Camaridium pendulum Barb. Rodr. ${ }^{8}$ belongs to a different species, also widespread in South America (illustrated in Hoehne, 1953; Sprunger et al., 1996). Surprisingly, camaridium pendulum and Ornithidium pendulum have never been confused despite being

\footnotetext{
${ }^{6}$ Scaphyglottis is a currently accepted genus in subtribe Laeliinae. Dressler (1960) designated Fernandezia graminifolia Ruiz $\&$ Pav. as the generic type of Scaphyglottis to preserve its modern circumscription and to avoid the massive nomenclatural changes that would have been required otherwise.

${ }^{7}$ Currently Camaridium micranthum M. A. Blanco. Blanco et al. (2007) had to propose a new name when transferring Maxillaria parviflora to Camaridium, because the specific epithet was already occupied by Camaridium parviflorum Fawc. (1910).

${ }^{8}$ Currently Ornithidium pendens (Pabst) Senghas. Pabst had to propose a new name when transferring Camaridium pendulum to Maxillaria, because the specific epithet was already occupied by Maxillaria pendula (Poepp. \& Endl.) C. Schweinf. (1945). Senghas (1993) maintained the specific epithet "pendens" when transferring the name to Ornithidium because "pendulum" was pre-occupied by Ornithidium pendulum (Poepp. \& Endl.) Cogn. (1904). This species also belongs in the Ornithidium clade (Whitten et al., 2007).
} 


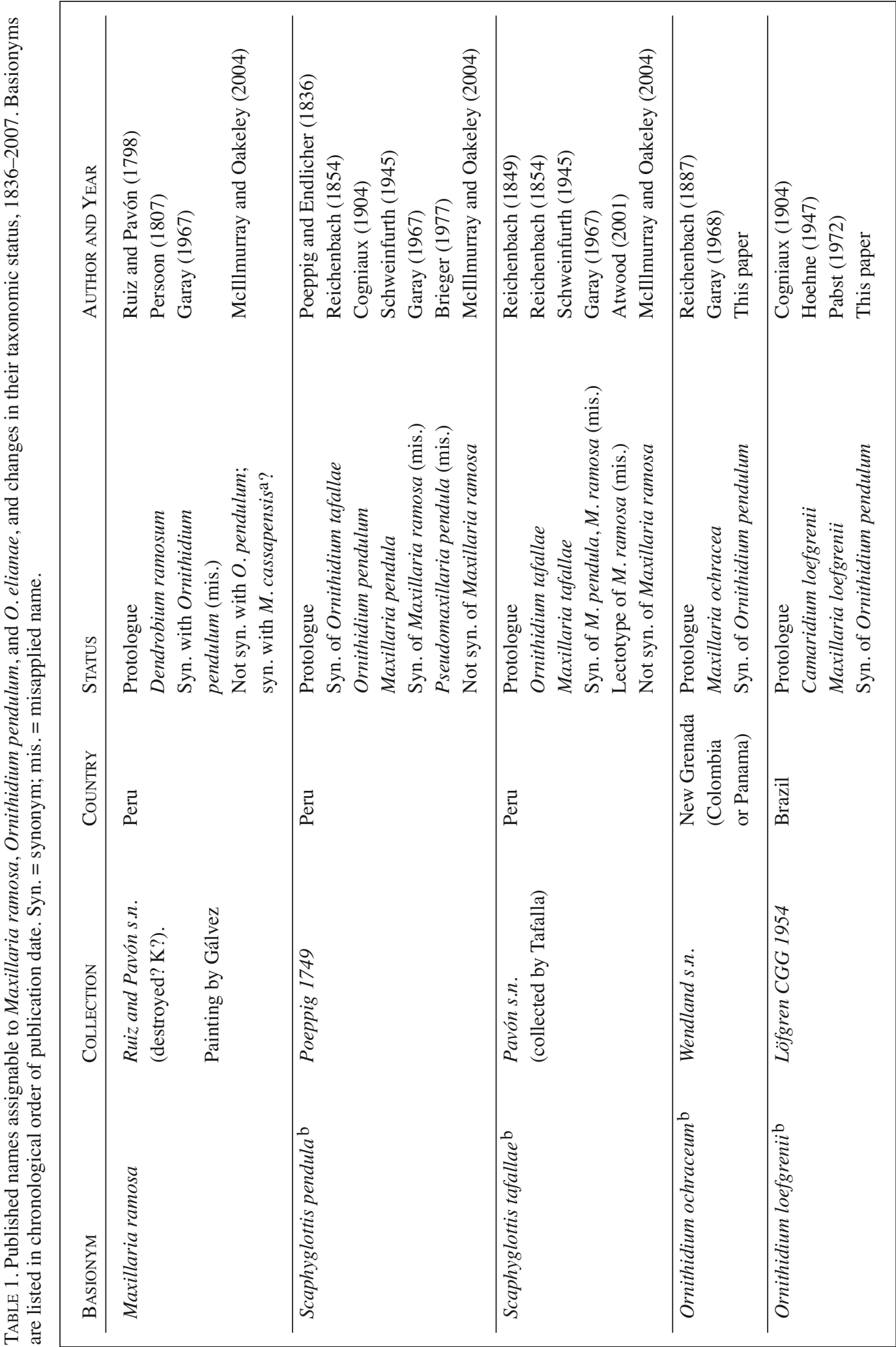


closely related and sharing the same specific epithet; therefore, Camaridium pendulum is not included in Table 1.

Scaphyglottis tafallae Rchb.f.

Reichenbach f. published this name in 1849 based on a Peruvian collection made by Juan Tafalla in 1797 (the earliest known collection of Ornithidium pendulum). A few years later, Reichenbach (1854) recognized Scaphyglottis tafallae as conspecific with $S$. pendula, but still transferred his species to Ornithidium and treated S. pendula as a synonym. Schweinfurth (1945), seemingly unaware of Reichenbach's synonymization, transferred both $S$.tafallae and $S$. pendula to Maxillaria (apparently he did not see their types either). In 1967, Garay put $M$. tafallae and M. pendula back together, but this time under the synonymy of $M$. ramosa (see "Confusion with Maxillaria ramosa Ruiz \& Pav." below).

The isotypes of Scaphyglottis tafallae at BM, $\mathrm{G}$, and MA have the unpublished name "Orchys ramosa" written on their labels ("Orchys" is a misspelling of the genus Orchis L.). The type collection was made by Juan Tafalla for Ruiz and Pavón, but only Pavón's name is written on the labels (at BM, G, and W), and only Ruiz's name was mentioned in the protologue. The date "Año 97" (year 1797) and the locality "Chicoplaya" is written on the labels of the specimens at G, MA, and $\mathrm{W}$, and is mentioned in the protologue. The isotype at $\mathrm{G}$ has an annotation by Reichenbach f. as "Ornithidium ramosum Rchb.f.," likely based on "Orchys ramosa," but he never published that combination.

Reichenbach (1856) cited two duplicates of Ornithidium tafallae, one in the Boissier herbarium $(\mathrm{G})$, and the other in Berlin; the latter was undoubtedly destroyed during the allied bombings of 1943 (Ames, 1944). Reichenbach (1856) misspelled the name as "O. Tabellae" (species number 67) but made reference to his transfer in Bonplandia 2: 18, and to the field data "Chicoplaya 1797." According to Garay (1967: 260), the specimen at $\mathrm{W}$ is made up of fragments (possibly taken by Reichenbach f.) from the specimen at $\mathrm{G}$, but it is also possible that they were taken from the now-destroyed specimen at B.

Mansfeld annotated the specimen at MA as Ornithidium tafallae in 1934, and Carnevali and Ramírez annotated it as the type of Maxillaria ramosa in 1988; this second annotation is incorrect (derived from Garay's misapplication of the 
name; see "Confusion with Maxillaria ramosa Ruiz \& Pav." below). In the same year, E. Christenson also annotated the specimen at BM as the type of M.ramosa.

\section{Ornithidium ochraceum Rchb.f.}

In 1887, Reichenbach f. described Ornithidium ochraceum based on a plant from "New Grenada" sent to him by Hermann Wendland, then director of the Royal Gardens in Herrenhausen (Hanover, Germany). Reichenbach even compared his "new" species to $O$. tafallae, but did not mention any differences. Garay transferred O. ochraceum to Maxillaria in 1968, but did not recognize it as conspecific with O.pendulum.

The type specimen of Ornithidium ochraceum is depauperate; it consists of a handful of aggregate, leafless pseudobulbs with a broken segment of rhizome at the base. However, there is a drawing of the plant attached to the sheet that clearly shows the characteristic leaf shape of $O$. pendulum, with one flower emerging from within the bracts at the base of the pseudobulb. It also shows the lip with a subtriangular, reflexed epichile with dark warts (mauve-colored spots, according to the protologue). No duplicates of the type collection have been located in GOET (J. Heinrichs, pers. comm.), where Wendland's main collection resides.

Both Schlechter (1920: 274) and Garay (1968: 235) assumed that the type of Ornithidium ochraceum was collected in modern-day Colombia. However, Panama was also part of the Republic of Nueva Granada at the time of publication of the protologue, and it is also possible that the type came from there. The specimen must have been prepared by Wendland from a plant cultivated at Herrenhausen, but not collected by him in the field. It is known that Wendland collected in Belize, Guatemala, Honduras, El Salvador, and Costa Rica (Wittmack, 1903; Stafleu and Cowan, 1988; Vegter, 1988), but there is no indication that he ever collected in Panama or Colombia.

\section{Ornithidium loefgrenii Cogn.}

Cogniaux described Ornithidium loefgrenii in 1904, in the same publication where he transferred Scaphyglottis pendula to Ornithidium, and thus failed to recognize both as conspecific (Cogniaux used the spelling "löfgrenii," which was corrected to "loefgrenii"; article 60.6 in McNeill et al., 2006). In 1942, Hoehne transferred $O$. loefgrenii to Camaridium, failing to recognize it as conspecific with Maxillaria pendula, even though he transcribed the original description of the latter species in the same publication. He repeated the same information in Flora Brasílica (Hoehne, 1953). Pabst transferred O. loefgrenii to Maxillaria in 1972. The name Maxillaria loefgrenii (Cogn.) Pabst therefore became widely used in Brazil, as this combination was used in the influential Orchidaceae Brasilienses (Pabst and Dungs, 1977).

The type specimen of Ornithidium loefgrenii was collected by Löfgren in São Paulo, Brazil. Hoehne (1953: t. 90) published a drawing of the type in which the shape of the labellum is almost identical to that illustrated by Lehmann for $O$. dichotomum Schltr. (Fig. 2). In an extensive molecular phylogeny of subtribe Maxillariinae (Whitten et al., 2007), O. pendulum (from Ecuador) is strongly supported as sister to $O$. loefgrenii (as Maxillaria pendula and M. loefgrenii, respectively), which provides support for their merging.

\section{Ornithidium dichotomum Schltr.}

Schlechter (1920) described Ornithidium dichotomum based on a plant collected by Friederich C. Lehmann in Popayán, Colombia, and compared it to O. tafallae. Schweinfurth (1945) referred Schlechter's species to the synonymy of Maxillaria tafallae (Rchb.f.) C. Schweinf.

There is a watercolor in Kew (F. C. Lehmann Icones No. 1005) based on Lehmann s.n. (B.T. $230, K)$, also from Popayán, that portrays the plant in life (Fig. 2).

The name Camaridium dichotomum Schltr. (synonym: Maxillaria dichotoma (Schltr.) L. O. Williams) belongs to a different species in the Camaridium clade, which occurs from Costa Rica to Peru (Atwood, 1999; Whitten et al., 2007).

\section{Maxillaria spathulata C. Schweinf.}

Schweinfurth described Maxillaria spathulata in 1952 from a Peruvian collection by Julio C. Vargas-Calderón. Schweinfurth even acknowledged a close relationship with $M$. tafallae, but distinguished M. spathulata by its larger flowers and differently shaped lip. We view these differences as part of the natural variation of $O$. pendulum, and possibly as artifacts from 
pressing, likely to happen in a flower bearing such a rigidly recurved labellum, which is almost impossible to flatten without any distortion.

Pabst referred Maxillaria spathulata to the synonymy of M. loefgrenii in 1972 . Here, we place these two names in the synonymy of $O$. pendulum for the first time.

\section{Unpublished names}

In the 1960's, A. H. Heller collected plants of Ornithidium pendulum in Nicaragua. Initially unaware of their identity, he intended to describe them as "Ornithidium nicaraguensis" and pre- pared an illustration and description (now in the archives at SEL). The prospective holotype (Heller 8403 at F, but not the duplicate at SEL), was annotated as "Ornithidium tafallae var. nicaraguensis Heller." Fortunately, these two names remained unpublished (the combination O. nicaraguense (Hamer \& Garay) M. A. Blanco \& Ojeda was coined for the species known until recently as Maxillaria nicaraguensis (Hamer \& Garay) J. T. Atwood; Blanco et al., 2007). A few years after Heller's death, Hamer $(1983,1990)$ annotated the specimens and published the illustration as Maxillaria ramosa.

\section{Confusion with Maxillaria Ramosa Ruiz \& PAV.}

The genus Maxillaria was established in 1794 by Ruiz and Pavón, and four years later they formally described 16 species in this genus, including M. ramosa. As in Scaphyglottis, the original characterization of the genus was vague and species descriptions were very generalized and therefore easily applicable to many other species currently known. Most of those original species of Maxillaria were eventually transferred to other genera. Only $M$. prolifera, $M$. platypetala, and M. ramosa remained within the genus until recently. For several years there was a heated debate on which of these should be regarded as the type of Maxillaria (Brieger and Hunt, 1969; Garay and Sweet, 1972; Ortiz, 1988; Senghas, 1993). After painstaking analyses, Maxillaria platypetala was finally chosen as the generic type (Garay, 1997; McIllmurray and Oakeley, 2001), a decision that has been widely accepted.

The type of Maxillaria ramosa was collected in the vicinity of Chinchao in Peru (Department Huánuco), and has the number 16 assigned to it. In the Delessert herbarium in Geneva there is an isotype of Scaphyglottis tafallae (= Ornithidium pendulum) with the unpublished name "Orchys ramosa," the number 16 and the name "Pavón" written on the label. Garay (1967) examined this specimen and assumed that it was the type of Maxillaria ramosa - an apparently logical, but erroneous conclusion. The name Maxillaria ramosa was widely misapplied to Ornithidium pendulum from then on (and soon afterward to O. elianae Carnevali \& M. A. Blanco as well; see under "Maxillaria ramosa auct., non Ruiz \& Pavón," at the end of the synonymy of $O$.pendulum, and in the usage synonymy of $O$. elianae, below). At one point, Garay and Sweet
(1972) even designated $M$. ramosa as the generic type of Maxillaria, based on the confused type of Scaphyglottis tafallae.

Garay's confusion was unearthed by McIllmurray and Oakeley (2001) when they found a painting prepared by Isidro Gálvez (one of the illustrators in the Ruiz and Pavón expedition to Peru) in the archives of the Real Jardín Botánico in Madrid (a photo of this painting was published by McIllmurray and Oakeley, 2001, 2004). The painting has the name Maxillaria ramosa on it, but depicts a plant clearly different from Scaphyglottis tafallae. McIllmurray and Oakeley (2001) wrongfully stated that the painting and the herbarium specimen corresponded to each other. This error was quickly pointed out by Atwood (2001) who, in a flawed attempt to stabilize the nomenclature, designated the herbarium specimen at Madrid as a lectotype of M. ramosa (following Garay's misapplication of the name).

Soon afterwards, McIllmurray and Oakeley (2004) demonstrated that the original description of Maxillaria ramosa and Gálvez's painting corresponded to each other, but not to the herbarium specimen in Madrid designated as a lectotype by Atwood (2001). Ruiz, Pavón, and Gálvez returned to Spain in 1788; some of their paid collectors, including Juan Tafalla, stayed in Peru and continued to send plants to Spain for Ruiz and Pavón's Flora Peruviana et Chilensis, and for Tafalla's own Flora Huayaquilensis (Estrella, 1991). It was Tafalla who collected the specimens labeled as "Orchys ramosa," which Reichenbach f. later used to describe Scaphyglottis tafallae in his honor. That Tafalla made this collection (and not Ruiz or Pavón) is evident by the year written down on the speci- 
men labels at G, MA, and W (1797, nine years after the return of Ruiz, Pavón, and Gálvez to Spain), and by the annotation "F. P." (present in the duplicates at MA and G) that Tafalla made on the labels of the plants collected for Flora Peruviana from 1793 onward (Estrella, 1991). Furthermore, Chicoplaya (the locality written on the label) was never visited by Ruiz and Pavón (Ruiz, 1940, 1998; McIllmurray and Oakeley, 2004), but it was visited by Tafalla between 1797 and 1798 (Estrella, 1995: 54). It seems that both Ruiz and Tafalla, by an unfortunate coincidence, used the same specific epithet ("ramosa") and the same number (16) for their collections of related but different species, both of which became types. Furthermore, Tafalla did not write his name on the labels but Pavón did, probably because it was collected for him. All these factors contributed to the identity confusion. Additional evidence for this argument is presented by McIllmurray and Oakeley (2004).

McIllmurray and Oakeley (2004) correctly concluded that Tafalla's "Orchys ramosa" is conspecific with Scaphyglottis pendula and S.tafallae. They also suggested that the name Maxillaria ramosa corresponds to $M$. cassapensis Rchb.f. (now Maxillariella cassapensis (Rchb.f.) M. A. Blanco \& Carnevali, a member of the Maxillaria graminifolia (Kunth) Rchb.f. suballiance sensu Atwood, 2003b), a conclusion we agree with. Therefore, Maxillaria ramosa is likely an older synonym of Maxillariella cassapensis (but see below). A fruiting specimen of M. cassapensis from the Ruiz and Pavón collections (annotated "Orchys, Ex Herb. de R \& P,
Lima") and later incorporated in Hooker's herbarium (now in the general collection at K), might represent type material of $M$. ramosa. Thus, Atwood's (2001) lectotypification of $M$. ramosa must be rescinded. McIllmurray and Oakeley (2004: 35) claimed that they designated the painting of Gálvez as the lectotype of $M$. ramosa in their previous (2001) publication, but they did not comply with article 7.11 of the Code (to include the phrase "designated here" or an equivalent, a requirement since 1 January 2001) and thus their lectotypification is invalid.

In any case, McIllmurray and Oakeley (2004) conclusively demonstrated that Maxillaria ramosa and Ornithidium pendulum are heterotypic names that correspond to separate species. However, their paper has been overlooked by some taxonomists of neotropical Orchidaceae. Only Christenson (2002b; but not in the original English version, 2002a) used the name $M$. ramosa in its correct, clarified new sense, when he assigned it to Maxillaria section Ebulbes Pfitz. (in the M. graminifolia suballiance sensu Atwood, 2003b). Given the long history of misapplication of the name $M$. ramosa, however, a case can be made for its rejection (see articles 56 and 57 in McNeill et al., 2006; M. A. Blanco, in prep.), and we opted for not transferring the name to Maxillariella (Blanco et al., 2007).

Whitten et al. (2007) used the name Maxillaria pendula, and Blanco et al. (2007) used the name Ornithidium pendulum in the sense used here. Sitko et al. (2006) used the misapplied name Maxillaria ramosa for Ornithidium pendulum.

\section{TAXONOMIC TREATMENT OF ORNITHIDIUM PENDULUM AND O. ELIANAE}

Ornithidium pendulum (Poepp. \& Endl.) Cogn., Fl. Bras. (Martius) 3(6): 92. 1904. Fig. 1-2.

Basionym: Scaphyglottis pendula Poepp. \& Endl., Nov. Gen. Sp. Pl. (Poeppig and Endlicher) 1: 58, t. 98. 1836; Maxillaria pendula (Poepp. \& Endl.) C. Schweinf., Bot. Mus. Leafl. 11: 285. 1945; Pseudomaxillaria pendula (Poepp. \& Endl.) Brieger, Bot. Jahrb. Syst. 97: 556. 1977; not Camaridium pendulum Barb. Rodr. TYPE: PERU. [Huánuco:] Cuchero, February 1830, E. F. Poeppig 1749 (Holotype: W-0007400; Isotype: WReich.-Orch. 40118).
Synonyms: Scaphyglottis tafallae Rchb.f., Linnaea 22: 855. 1849; Ornithidium tafallae (Rchb.f.) Rchb.f., Bonplandia 2: 18. 1854. Maxillaria tafallae (Rchb.f.) C. Schweinf., Bot. Mus. Leafl. 11: 288. 1945. TYPE: PERU. [Huánuco:] Chicoplaya, 1797, J. Tafalla sub Pavón s.n. (Holotype: WReich.-Orch. [40121]; Isotypes: B [destroyed], BM, MA, SEL [photo, not seen] , US [photo, not seen], G; Drawings: W-Reich.-Orch., AMES 38598).

Ornithidium ochraceum Rchb.f., Gard. Chron. 1: 209. 1887; Maxillaria ochracea (Rchb.f.) Garay, Caldasia 10: 235. 1968. Syn. nov. TYPE: NEW GRENADA 


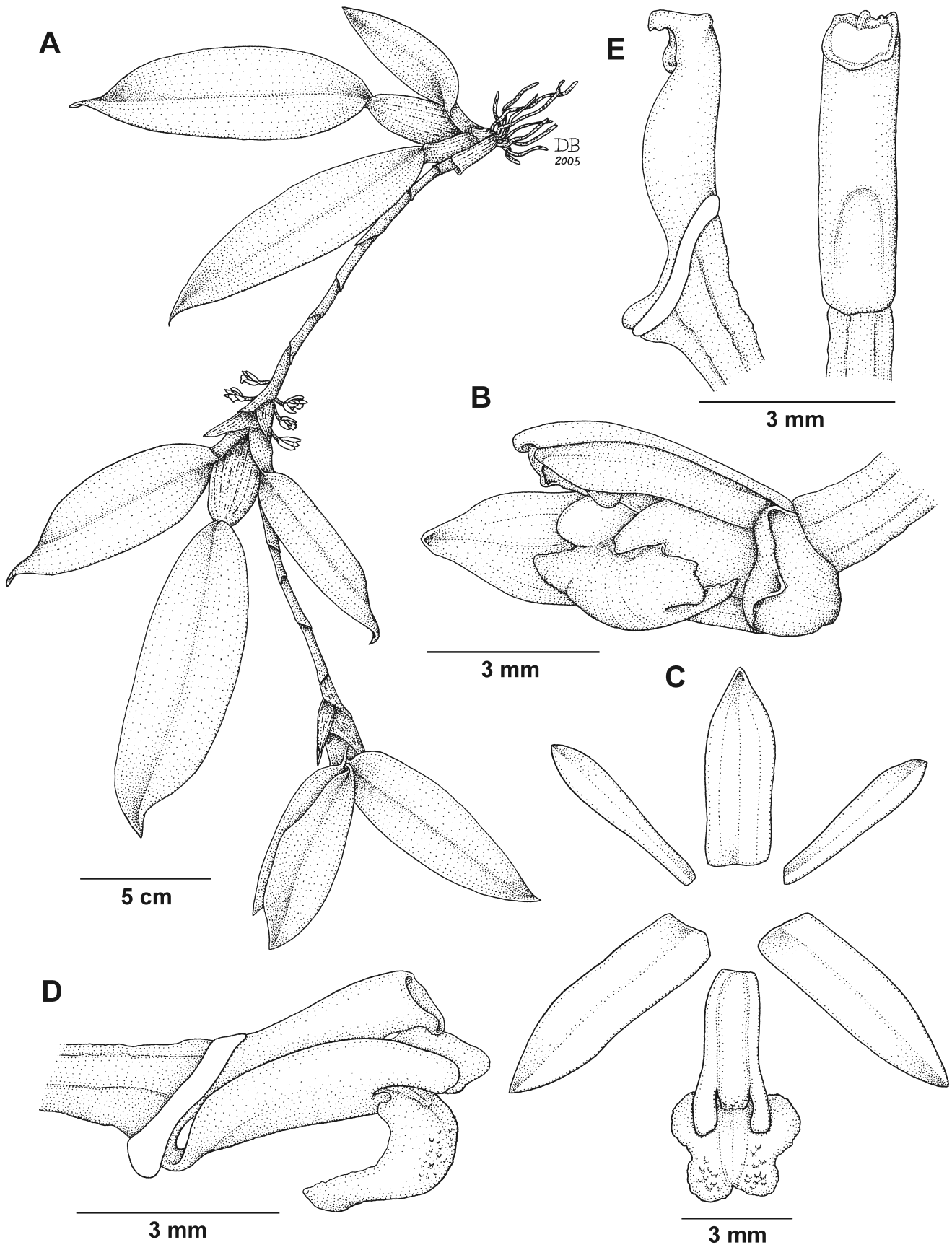

Figure 1. Ornithidium pendulum (Poepp. \& Endl.) Cogn. A, plant habit; B, flower, side view; C, dissected perianth; D, labellum and column attached to ovary, sepals and petals removed, side view; E, column, side (left) and ventral (right) views. Drawn by D. Bogarín from Karremans 448 (CR). 
(COLOMBIA or PANAMA). Ex Hort. Royal Gardens in Herrenhausen, Germany, H. Wendland s.n. (Holotype: WReich.-Orch. 40122).

Ornithidium loefgrenii Cogn., Fl. Bras. (Martius) 3 (6): 92. 1904, 'löfgrenii'; Camaridium loefgrenii (Cogn.) Hoehne, Arq. Bot. Estado São Paulo n.s., formato maior 2(4): 72. 1947; Maxillaria loefgrenii (Cogn.) Pabst, Bradea 1(19): 175. 1972. Syn. nov. TYPE: BRAZIL. [São Paulo, Campo Grande; fide protologue], cult. na Capital [São Paulo city, capital of São Paulo state; fide Hoehne, 1953], 20 January 1894, A. Löfgren CGG 1954 (Holotype: SP).

Ornithidium dichotomum Schltr., Repert. Spec. Nov. Regni Veg. Beih. 7: 178. 1920; illustration in Repert. Spec. Nov. Regni Veg. Beih. 57: t. 63, nr. 245. 1929; not Camaridium dichotomum Schltr. TYPE: COLOMBIA. Cauca: An Bäumen auf dem Hochland von Popayan, 1400-1800 m, [1884-1900], F. C. Lehmann 8114 (Holotype: B [destroyed]; Lectotype, designated here: K-79237; Isolectotype: K79236).

Maxillaria spathulata C. Schweinf., Bot. Mus. Leafl. 15: 164, t. 54. 1952. Syn. nov. TYPE: PERU. Cuzco: Prov. Paucartambo, between Santa Isabel and Asunción, 1800 m, 4 January 1946, J. C. Vargas-Calderón 5532 (Holotype: AMES; Isotype: CUZ [not seen]).

"Maxillaria ramosa" auct. non Ruiz \& Pav.: Garay in Bot. Mus. Leafl. 21: 259. 1967; Schweinfurth in Fieldiana, Bot. 33: 64, 65. 1970; Garay and Sweet in J. Arnold Arbor. 53: 524. 1972; Dodson and Gentry in Selbyana 4: 170. 1978; Dodson and Dodson in Icon. Pl. Trop. 2: 161. 1980; Hamer in Ic. Pl. Trop. 9: 865. 1983; Siegerist in Selbyana 7: 298. 1984; Ortiz in Orquideología 17: 237. 1988; Hamer in Selbyana 11 (Suppl.): 486. 1990; Brako and Zarucchi in Monogr. Syst. Bot. Missouri Bot. Gard. 45: 820. 1993; Senghas in Orchideen (Schlechter), ed. 3, 1B: 1771. 1993; Ortiz in Orquídeas de Colombia, ed. 2: 284. 1995; Jørgensen and León-Yánez in Cat. Vasc. Pl.
Ecuador: 706. 1999; Dix and Dix in Monogr. Syst. Bot. Missouri Bot. Gard. 78: 33. 2000; Atwood in Orch. Rev. 109: 316. 2001; Hamer in Monogr. Syst. Bot. Missouri Bot. Gard. 85: 1756-1757. 2001; Dodson in Native Ecuadorian Orchids 3: 562. 2002; Dodson in Native Ecuadorian Orchids 5: 1134. 2004; Ossenbach et al. in Orquídeas del Istmo Centroamericano: 96, 214. 2007.

"Maxillaria repens" auct. non L. O. Williams: Dix and Dix in Monogr. Syst. Bot. Missouri Bot. Gard. 78: 33. 2000; Govaerts et al. in World Checklist of Orchidaceae, 2005 (in both as synonym of M. ramosa).

"Ornithidium tafallae var. nicaraguensis" Heller, in sched. (A. H. Heller 8403, F).

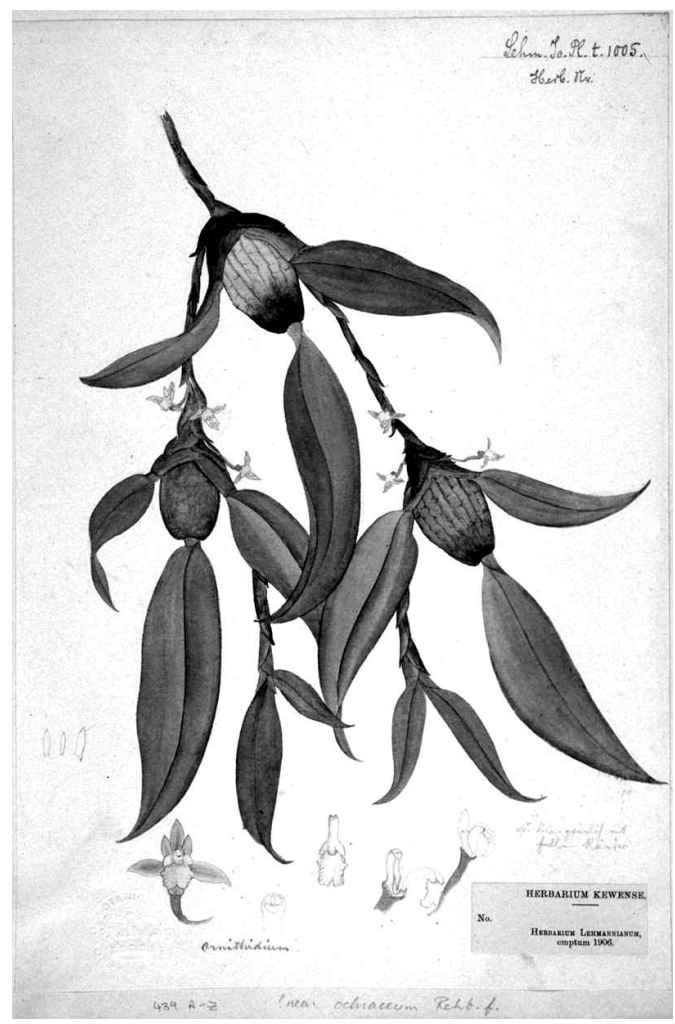

FIGURE 2. Ornithidium pendulum (Poepp. \& Endl.) Cogn. Photo of painting No. 1005 by F. C. Lehmann, based on Lehmann s.n. (B.T. 230, K), from the type locality of $O$. dichotomum Schltr. Reproduced with the kind permission of the Trustees, Royal Botanic Gardens, Kew. 
Epiphytic or lithophytic herbs, to $2 \mathrm{~m}$ long, most commonly to $70 \mathrm{~cm}$ long or less; plants pendent or scandent, with stems branching at the bases of pseudobulbs. Roots cylindrical, $1 \mathrm{~mm}$ in diameter. Stems sympodial, always terminated by a pseudobulb. Rhizome to 3-4 $\mathrm{mm}$ diameter, first covered with thin, scarious, acute, green sheaths, eventually brownish or gray with age; branches divaricate, usually 2 , produced from the axils of consecutive non-foliar bracts immediately behind the pseudobulb; the segments of rhizome between pseudobulbs made up of few, elongate internodes, the pseudobulbs 5-20 cm apart on the rhizome, occasionally groups of $2-3$ pseudobulbs growing close together. Pseudobulbs $2.5 \mathrm{~cm}$ long, 1.5-5.0 cm wide, $0.7-1.5 \mathrm{~cm}$ thick, brownish to gray-green at the base, grading to silvery green at apex; plump and smooth when young, slightly wrinkled when old, apically 1-leaved, ellipsoid, ovoid to (rarely) suborbicular, basally clothed by several imbricate sheaths of which the (12(-4) innermost bear foliar blades, these eventually caducous. Leaves and blades of sheaths bright green, subcoriaceous, smooth, fleshy, conduplicate, articulate, twisted 90 degrees at base so that all the leaves face to the same side; elliptic to oblong or linear-elliptic, the margins often suffused with purple and slightly revolute, the apex acute to shortly acuminate, oblique because one of the halves is conspicuously shorter than the other, keeled abaxially, $8-20 \mathrm{~cm}$ long, 2.4-5.0 cm wide, the innermost sheath blade larger than the apical leaf and the outermost smaller, the sheaths $2-5 \mathrm{~cm}$ long. Inflorescences numerous, 1-flowered, with thin peduncles, borne singly or several from the axils of the sheaths enveloping the pseudobulbs and from the bracts at any point along the rhizome, several flowers open simultaneously along any given rhizome segment; peduncle 1-2 cm long, cylindrical, basally with $1-3$ thin, soft, brown bracts; ovary with pedicel $6-8 \mathrm{~mm}$ long; floral bracts tubular, acuminate. Flowers small and inconspicuous, to $1 \mathrm{~cm}$ long, usually resupinate, sepals and petals greenish-white, often suffused with pink, and sometimes deep gray-brown; lip white to ochre-yellow, frequently with purple spots, more rarely with pink tinges, the column greenish. Sepals 5.5-10.0 mm long, $1.7 \mathrm{~mm}$ wide, rectangular, oblong, acute, concave basally, flat to convex distally, the lateral sepals slightly oblique, somewhat longer and wider than dorsal sepal, basally produced into a small, obtuse mentum. Petals 5-9 mm long, 1.0-1.5 $\mathrm{mm}$ wide, linear-elliptic, oblong to oblongoblanceolate to narrowly obovate oblanceolate, acute. Labellum $6 \mathrm{~mm}$ long, $3 \mathrm{~mm}$ wide, rectangular and narrow at the base, 3-lobed, the lateral lobes $4.0-6.0 \mathrm{~mm}$ long, $0.5-8.0 \mathrm{~mm}$ wide, rectangular, straight and parallel to the column in natural position, partially surrounding the column; the central (apical) lobe sharply to obscurely 4-lobulate, 3-2 mm long, 3.6-8.0 mm wide, the margin finely denticulate, apically emarginate, thickened and often verrucose in the central part, strongly reflexed in natural position; the callus to $4 \mathrm{~mm}$ long, rectangular and shorter than the lateral lobes, consisting of a transverse plate at the union of the lateral lobes with the central lobe. Column subcylindric, ventrally gibbous, basally produced into a short foot, to $4.7 \mathrm{~mm}$ long; anther cap cucullate, palebrown; pollinia 4, in two unequal pairs attached to a short ligulate stipe and a tiny semilunar viscidium. Fruit an ovate, pendent, dehiscent capsule, 9-12 mm long, 7-8 $\mathrm{mm}$ wide, valves separating apically upon maturity.

Habitat and ecology: plants grow as hanging epiphytes or lithophytes and can become large, pendent mats. The species occurs at 400-1800 $\mathrm{m}$ in montane and lower montane, wet and cloud forests. The small green to yellowish flowers suggest that pollinators are flies or small bees, but no floral visitors have ever been documented.

Phenology: flowering occurs sporadically throughout the year.

Conservation status: a widespread species and common along the eastern tropical Andes. It is rare in other parts of its distribution, but this rarity appears to be natural, not anthropogenic. This species is not threatened.

Illustrations: detailed analytical drawings have been published under the names Maxillaria spathulata (Schweinfurth, 1945), Camaridium loefgrenii (Hoehne, 1953), Maxillaria ochracea (Dunsterville and Garay, 1976; Bennett and Christenson, 1993; Romero and Carnevali, 2000) and Maxillaria ramosa (Dodson and Gentry, 1978; Dodson and Dodson, 1980; Hamer, 1983, 1990; Senghas, 1993; Dodson, 2002). Some of these (e.g., Bennett and Christenson, 1993) depict the plant as erect, although it is normally pendent. 
Photographs of Ornithidium pendulum appear in Senghas (1993, as M.ramosa), Miller and Warren (1994, 1996, as M. loefgrenii), and Fernández (2004, as M. ochracea).

Distribution: one of the most widely distributed species in the genus (as circumscribed by Whitten et al., 2007, and Blanco et al., 2007). In South America it is recorded from western Venezuela, Colombia, Ecuador, Peru, and southeastern Brazil; it is locally common in parts of Rio de Janeiro state in Brazil (Miller and Warren, 1994, 1996; Miller et al., 2007; as Maxillaria loefgrenii) and along the eastern Andes from Colombia to northern Peru, but it is rare and patchily distributed elsewhere. It appears to be absent in the Guiana Shield and most of the Amazonian lowlands.

In Venezuela, Ornithidium pendulum is only known in the Andean (western) states of Lara, Mérida, Táchira, Trujillo, and Zulia where it is local and rare. Brazilian populations (hitherto classified as Maxillaria loefgrenii) appear to be disjunct from those in the Andes, and are confined to the Atlantic coastal mountain range in the states of Espírito Santo, Rio de Janeiro, and São Paulo (possibly also in southern Bahia state), where they are also patchily distributed.

Hamer (1983) mentions this species (as Maxillaria ramosa) as being present in Bolivia, but he did not cite any specimens; his record is probably based on the closely related Ornithidium sillarense (Dodson \& Vásquez) M. A. Blanco \& Ojeda (see below).

We also present the first record of Ornithidium pendulum for Costa Rica (see specimens examined). In Central America, this species had been previously recorded (as $M$. ramosa) for Nicaragua (Hamer, 1983, 1990, 2001) and Guatemala (Dix and Dix, 2000).

Additional specimens examined: BRAZIL. Espírito Santo: Santa Teresa, morro da estação repetidora de TV, 14 November 1985, Boone 880 (MO). COLOMBIA. [Cauca:] Popayán, Lehmann s.n. (B.T. 230, K). Region of Popayán, flowered in cultivation, SEL 72-1200, 9 May 1979, Kennedy s.n. (SEL [26960]). COSTA RICA. Cartago: Turrialba, Centro Agronómico Tropical de Investigación y Enseñanza (CATIE), $600 \mathrm{~m}$, flowered in cultivation at Lankester Botanical Garden, 31 October 2004, Karremans 448 (CR). ECUADOR. El Oro: $10 \mathrm{~km} \mathrm{~W}$ of Piñas along the new road from Piñas to
Machala, 900 m, 19 July 1979, Dodson et al. 8439 (MO, SEL). Esmeraldas: $\mathrm{km} 16$ Esmeraldas to Santo Domingo, $300 \mathrm{~m}, 13$ September 1980, Dodson et al. 10436 (SEL). Quninde. Bilsa Biological Station, Montañas de Mache, $35 \mathrm{~km} \mathrm{~W}$ of Quinindé, $5 \mathrm{~km} \mathrm{~W}$ of Santa Isabel, $00^{\circ} 21^{\prime} \mathrm{N}, 79^{\circ} 44^{\prime} \mathrm{W}, 400-600 \mathrm{~m}, 5$ May 1995, Clark and Watt 742 (MO, QCNE, US). Los Rios: Rio Palenque Science Center, km 56 Quevedo-Santo Domingo, 220 m, 20 September 1973, Dodson and Tan 5398 (RPSC, SEL); flowered in cultivation, 9 May 1979, Dodson et al. 9275 (SEL). Morona-Santiago: above Sucua, 800 m, 23 April 1982, Dalström 217 (SEL). Road from El Pangui to Chiguinda, km 18, $03^{\circ} 19^{\prime} 29^{\prime \prime} \mathrm{S}, 78^{\circ} 38^{\prime} 59^{\prime \prime} \mathrm{W}, 1200 \mathrm{~m}, 3$ October 2003, Whitten et al. 2513 (FLAS, QCA). Cultivated at Ecuagenera greenhouses in El Pangui, origin uncertain, 3 October 2003, Whitten et al. 2487 (FLAS, QCA). Napo: Archidona, Reserva de Biósfera Sumaco, $00^{\circ} 40^{\prime} 03^{\prime \prime} \mathrm{S}, 77^{\circ} 35^{\prime} 40^{\prime \prime} \mathrm{W}, 18$ February 2003, Farfán 431 (MO, QCNE); Cordillera de

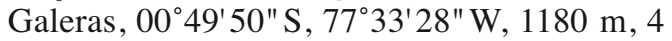
March 2003, Farfán 460 (MO). La Cruz, Arajuno, Puerto Misahualli, Rio Napo, 500 m, July-September 1984, Suarez and Lindberg de Suarez 44 (RPSC). Pastaza: Km 7 Puyo to Mera on road Baños to Puyo, 1000 m, 17 June 1989, Dodson and Niell 17413 (QCNE, RPSC). Pichincha: Cooperativa Santa Marta \#2, km 3 W of bypass around Santo Domingo, $530 \mathrm{~m}, 22$ July 1979, Dodson et al. 8514 (SEL). Tungurahua: Topo, at junction of Rio Topo and Rio Pastaza, 1300 m, 10 December 1986, Dodson and Hagsater 16741 (RPSC). ZamoraChichinpe: Rio Bombuscara, $2 \mathrm{~km}$ E of Zamora city, 900 m, 18 May 1967, Sparre 16389 (MO). Road Los Encuentros to Rio Machinaza, NW portion of Cordillera del Condor, 1450-1650 m, 19 May 1988, Hirtz 3792 (QCNE, RPSC). Zamora-Cenepa, Rio Zamora, 1100 m, 26 July 1960, Dodson 161 (SEL). Zumbi, N border of Rio Zamora, 900 m, 18 May 1967, Sparre 16467 (MO). GUATEMALA. Alta Verapaz: Cobán, Rio Sanchichaj, February 1990, Dix et al. 6986 (UVAL [flowers in liquid]). NICARAGUA. [Rivas: Ometepe Island, Volcán Maderas, $4000 \mathrm{ft}$ (fide Heller's notes at SEL)], Heller 8403 (F, SEL). PERU. Amazonas: Rio Cenepa, creek flowing into Nahim, which flows into the Huampami, trail E of Huampami, 1 day 
walk to Shaim, $2000 \mathrm{ft}, 27$ November 1972, Berlin 402 (MO, SEL). Huánuco: Huánuco, Tingo María, Rio Huallaga, 19 July 1940, Asplund 12373 (AMES). Leoncio Prado, Distr. Damaso Beraun, Las Palmas, 880 m, UTM 18L 0394213-894790, Trujillo 316 (HAO, URP). Junín: Rio Pinedo, N of La Merced, 700-900 m, 30 May 1929, Killip and Smith 23650 (AMES). San Ramón, 900-1300 m, 9 June 1929, Killip and Smith 24762 (AMES). Pasco: Oxapampa, headwaters of Rio Tunqui, trail to ChuchurrasPalcazu, $10^{\circ} 14^{\prime} \mathrm{S}, 75^{\circ} 28^{\prime} \mathrm{W}, 1850 \mathrm{~m}, 2$ January 1984, Foster et al. 7783 (MO). Between La Merced and Oxapampa, 1400 m, 30 January 1979, Luer 3809 (SEL). San Martín: Lamas, distr. Alonso de Alvarado, San Juan de Pacaizapa, km 72 carretera TarapotoMoyobamba, 1000-1050 m, 8 June 1977, Schunke 9661 (MO). Zepelacio, near Moyobamba, 1200-1600 m, January 1934, Klug 3544 (MO); 1100 m, June 1934, Klug 3694 (AMES). VENEZUELA. Lara: $1350 \mathrm{~m}, 18$ October 1952, Renz 7839 (RENZ). Mérida: 1600 m, 26 March 1949, Renz 5119 (RENZ). Miranda: Quinta Colibría, 1400 m, cultivated in orchidarium of Mr. and Mrs. G. C. K. Dunsterville [plant originally from Zulia, Sierra de Perijá], 13 October 1963, Steyermark and Dunsterville 56254 (VEN). Táchira: 12 March 1951, Renz 6667 (RENZ). Zulia: Sierra de Perijá, entre Pishicaco y la frontera con Colombia hacia Socorpa, $1500 \mathrm{~m}$, floreciendo en Caracas, December 1974, Dunsterville s.n. (VEN).

Ornithidium pendulum is vegetatively indistinguishable from the Bolivian O. sillarense, and both species are obviously very closely related. The flowers are very similar, but the labellum of $O$. sillarense is distinct enough to warrant specific recognition: the midlobe is almost twice as long as the rest of the labellum (vs. subequal or smaller than the rest of the labellum in O.pendulum), is not reflexed, and has a different shape. We have not seen intermediate forms in terms of labellum structure. As far as we know, Ornithidium pendulum has not been collected in Bolivia. According to the protologue, the holotype of $O$. sillarense was deposited in MO. However, it is presently housed in Herbarium Vasquezianum in Bolivia (R. Vásquez, pers. comm., 2006). A previously unreported isotype of $O$. sillarense was recently found in SEL.
Both Dix and Dix (2000) and Govaerts et al. (2005) treated Maxillaria repens L. O. Williams (now Ornithidium repens (L. O. Williams) M. A. Blanco \& Ojeda) as a synonym of $O$. pendulum (as M. ramosa). However, O. repens is a different species endemic to Panama, easily distinguished from $O$. pendulum by its more robust, ascending rhizomes devoid of pseudobulbs.

Herbarium specimens of Ornithidium pendulum have been commonly annotated as Maxillaria loefgrenii (those from Brazil), $M$. ochracea, or M. ramosa.

Ornithidium elianae Carnevali \& M. A. Blanco, sp. nov. TYPE: VENEZUELA. Estado Carabobo: Municipio Autónomo Mora, cuenca hidrográfica del rio Morón, parte alta, bosque nublado, $10^{\circ} 17-28^{\prime} \mathrm{N}, 68^{\circ} 10-16^{\prime} \mathrm{W}, 700-1100$ m, 13-15 April 1991 (flowers), Wilmer Díaz 110 (Holotype: VEN; Isotypes: MO, PORT). Fig. 3. Usage synonyms: Maxillaria taphallae (sic.) auct. non Rchb.f.: Dunsterville and Garay in Venez. Orch. Ill. 1: 242-243. 1959; Dunsterville and Dunsterville in Amer. Orchid Soc. Bull. 36: 794. 1967; 38: 496. 1969.

Maxillaria ramosa auct. non Ruiz \& Pavón: Foldats in Fl. Venez. 15(4): 516. 1970; Dunsterville and Garay in Venez. Orch. Ill. 6: 37. 1976; Steyermark and Huber in Fl. Avila: 680, 697. 1978; Dunsterville and Garay in Orchids Venezuela: 545. 1979; Cremers and Hoff in Invent. Taxon. Pl. Guyane Franc. II Orchidac.: 54. 1992; Boggan et al. in Checkl. Pl. Guianas, ed. 2: 158. 1997; Romero and Carnevali in Orchids Venezuela, ed. 2: 581. 2000; Clarke et al. in Sida, Bot. Misc. 21: 50. 2001; Carnevali and Ramírez in Fl. Venez. Guayana 7: 442. 2003; Chiron and Bellone in Orch. Guyane Franc.: 264. 2005; Funk et al. in Contr. U.S. Natl. Herb. 55: 127. 2007.

Species haec Ornithidio pendulo (Poepp. \& Endl.) Cogn. similis, foliis angustioribus, labelli lobulo apicale oblongo concavo (vs. ovato vel ovato oblongo convexo recurvo) abhorret.

Epiphytic or rarely lithophytic herbs, to 1.5 $\mathrm{m}$ long, most commonly to $50 \mathrm{~cm}$ long or less; plants first suberect or sprawling to creeping, 


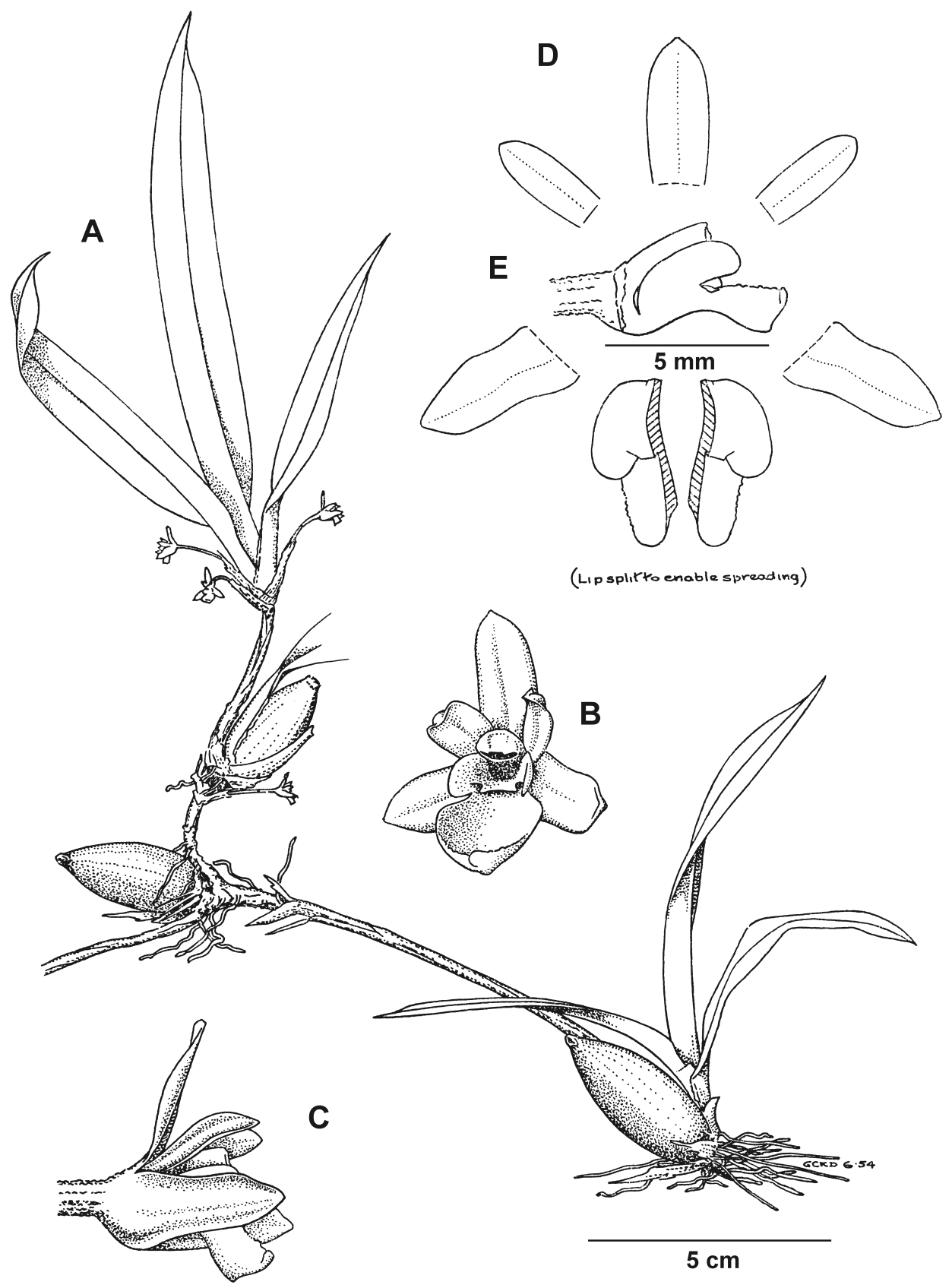

FIGURE 3. Ornithidium elianae Carnevali \& M. A. Blanco. A, plant habit; B, flower, front view; C, flower, side view; D, dissected perianth; E, labellum and column attached to ovary, sepals and petals removed, side view. Drawn by G. C. K. Dunsterville from Dunsterville 204 (voucher not found), from Guatopo (Estado Miranda, Venezuela). This illustration was published as Maxillaria "taphallae" Rchb.f. (sic.) in Dunsterville and Garay (1959), and as M. ramosa Ruiz \& Pav. in Dunsterville and Garay $(1976: 37 ; 1979)$ and Romero and Carnevali (2000). 
eventually arching to pendent, usually growing on thick branches or tree boughs in cloud forests. Roots cylindrical, $1 \mathrm{~mm}$ in diameter. Stems sympodial, always terminated by a pseudobulb. Rhizome to $4 \mathrm{~mm}$ diameter, first covered with thin, scarious, eventually evanescent sheaths, becoming naked and brownish; branches divaricate, usually two, produced from the axils of consecutive non-foliar bracts immediately behind pseudobulb; the segments of rhizome between pseudobulbs made up of few, elongated internodes, the pseudobulbs 5-20 cm apart on the rhizome. Pseudobulbs $1.5-4.2 \mathrm{~cm}$ long, 1.4-2.5 cm wide, silvery gray-green, grading to silvery-brown, smooth and slightly wrinkled, apically 1-leaved, ellipsoid, ovoid to (rarely) suborbicular, slightly laterally compressed, clothed by several imbricate sheaths of which the 1(-2) innermost bear foliar blades; leaves and sheath blades early caducous (mature pseudobulbs usually devoid of them). Leaves and the blades of the sheaths bright green, subcoriaceous, conduplicate, articulate, linear-elliptic, narrowly elliptic to narrowly oblong-elliptic, the margins slightly revolute, the apex acute to shortly acuminate, oblique due to the fact that one of the halves is conspicuously shorter than the other, keeled abaxially, $3.5-17.0 \mathrm{~cm}$ long, $0.5-1.6(-2.3) \mathrm{cm}$ wide, the sheaths $2-3 \mathrm{~cm}$ long. Inflorescences 1 -flowered, borne singly or several from the axils of the sheaths enveloping the developing or youngest pseudobulbs, up to 20 flowers produced successively per shoot over a long period, only 1-3(-4) flowers are open on any given shoot simultaneously; peduncle 10$15 \mathrm{~mm}$ long, cylindrical, basally with 1-2 thin, soft, brown bracts; ovary with pedicel 5.5-6.5 $\mathrm{mm}$ long, floral bracts ca. $3 \mathrm{~mm}$ long, tubular, acuminate. Flowers small and inconspicuous, resupinate, subcampanulate, perianth segments white or greenish-white, more rarely with pink tinges, the column greenish-yellow; the petals and sepals thin-membranous, almost translucent, with a heavily thickened midnerve dorsally which is slightly sulcate on the inner face. Sepals 4.5-6.0 mm long, 1.7-2.2 $\mathrm{mm}$ wide, oblong elliptic to lanceolate, obtuse to acute, basally concave, flat to convex distally, the lateral sepals slightly oblique, somewhat longer and wider than dorsal sepal, basally produced into a small, obtuse mentum. Petals $3.5-5.0 \mathrm{~mm}$ long, 1.2-1.7 $\mathrm{mm}$ wide, oblong to oblong- oblanceolate to narrowly obovate-oblanceolate, acute to obtuse. Labellum 4-7 mm long, 2.5-4.0 $\mathrm{mm}$ wide upon flattening, in general outline elliptic to obovate-elliptic from a subcuneate base; rigidly attached to the column foot, 3lobed below middle, middle lobe $2.5-3.1 \mathrm{~mm}$ long, 2.2-2.9 $\mathrm{mm}$ wide, oblong subquadrate to almost suborbicular, smooth, apically emarginate to bilobed, the margins erect (thus the lobe deeply concave), the margin finely dentate to irregularly crenate; lateral lobes $1.0-1.5 \mathrm{~mm}$ long, ca. $0.7 \mathrm{~mm}$ wide, erect, porrect in natural position and enfolding the column, the free portions suborbicular to elliptic; the disk provided with a callus consisting of a transverse plate between the bases of the lateral lobes. Column subcylindric, relatively short and thick, basally produced into a short foot, $2.8-4.1 \mathrm{~mm}$ long; pollinia not seen. Fruit an ovate, pendent, dehiscent capsule, $9 \mathrm{~mm}$ long, $7 \mathrm{~mm}$ wide, valves separating apically upon maturity.

Habitat and ecology: locally common in many places of the Venezuelan Coastal Range at $600-1600 \mathrm{~m}$, frequently in cloud forests. The plants grow as creeping epiphytes first, but eventually become huge, heavy mats and their long stems become arching and pendent. Plants are often found fallen on the forest floor after storms or severe rainfall, but are incapable of surviving in the deep shade of the cloud forest understory and eventually die (G. Carnevali, pers. obs.).

Phenology: data from herbarium specimens and from records published by Dunsterville and Dunsterville (1967; as Maxillaria ramosa) indicate that flowering occurs sporadically throughout the year.

Conservation status: common only in the coastal cordillera of northern Venezuela, but it is protected in several national parks in that area (Canaima, El Avila, Guatopo, Macarao, San Esteban, and Yurubí; G. Carnevali, pers. obs.). This species is not threatened.

Illustrations: first illustrated by Dunsterville and Garay (1959) as Maxillaria "taphallae" (sic.); this illustration is reproduced here (Fig. 3). After Garay's (1967) unfortunate confusion, Dunsterville and Garay (1976: 37) changed the name to Maxillaria ramosa, and illustrated $O$. pendulum under its synonym Maxillaria ochracea. These confused determinations were perpetuated in Orchids of Venezuela: An 
Illustrated Field Guide (Dunsterville and Garay, 1979) and its recent revised edition (Romero and Carnevali, 2000). Foldats (1970) also cited and illustrated $O$. elianae as Maxillaria ramosa.

Eponymy: named after Eliana Noguera, curator of Orchidaceae in the Venezuelan National Herbarium (VEN) who kindly provided us with material, data, and images of this novelty, $O$. pendulum, and other related species from Venezuela.

Distribution: known from northern Venezuela (where it is relatively common and widespread) and the Guiana Shield (in southern Venezuela, Guyana, Surinam, and French Guiana, where it is local and rare). In Venezuela, it occurs in the Sierra de San Luis, the Coastal Range (including Caracas; Dunsterville and Dunsterville, 1969; as Maxillaria ramosa), and from two collections in the Venezuelan Andes (where both $O$. elianae and $O$. pendulum are rare but potentially sympatric). There is an unconfirmed report of this species from Cerro Auyantepui in the Venezuelan Guayana (Foldats, 1970; Carnevali and Ramírez, 2003; Funk et al., 2007). It is also known from a single collection in western Guyana, and is reported from French Guiana and Surinam (Cremers and Hoff, 1992; Boggan et al., 1997; Chiron and Bellone, 2005; Funk et al., 2007; all as $M$. ramosa, vouchers not seen by us); these reports are from areas adjacent to the known distribution of $O$. elianae and most likely represent this species instead of $O$. pendulum, which has not been collected in the Guiana Shield.

Ortiz's illustration of "Maxillaria ramosa" (Ortiz, 1988, 1995) is a crude tracing of Dunsterville's line drawing of O. elianae (Fig. 3). As far as we know, however, O. elianae does not occur in Colombia.

Additional specimens examined: GUYANA. Cuyami-Mazaruni, Paruima, 9 km W, Ararata scrub area, $05^{\circ} 49^{\prime} \mathrm{N}, 61^{\circ} 08^{\prime} \mathrm{W}, 800 \mathrm{~m}, 3$ July 1997 (fruit), Clarke et al. 5252 (US). VENEZUELA. Aragua: Dpto. Girardot, Rancho Grande bei Maracay, Parque National Regenwald, 1400 m, 22 May 1963 (flowers), Renz 10203 (RENZ). Carabobo: cabeceras del Rio San Gián, arriba de La Toma, al sur de Borburata, 800 m, 30 March 1966 (flowers), Steyermark and Steyermark 95631 (VEN). Distrito Federal: Cerro Naiguatá, arriba del pueblo de Naiguatá, Lomas de Las Delicias, entre Quebrada de Basenilla y Quebrada Guayoyo, 9-12 km suroeste de Hacienda Cocuizal. 1500-1635 m, 15-19 November 1963 (sterile), Steyermark 92010 (AMES, ECON, VEN). Falcón: Sierra de San Luis, entre La Chapa y Uria, 1400 m, 19 July 1967 (sterile), Steyermark 99199 (AMES). Mérida: Pico Espejo, 18 January 1964 (flowers), Ehiendorfer s.n. (WU). Bei Rodeo Grande, collected by Ehiendorfer, cultivated in the Botanisches Institut der Universität Wien, 26 January 1971 (flowers), Vöth s.n. (WU). Trujillo: Quebrada Palmichero, between Escuque and Mt. Carmelo, $1400 \mathrm{~m}$, flowered in cultivation in Trujillo, 15 April 1949 (flowers), Renz 5378 (RENZ). Yaracuy: Distrito San Felipe, cabeceras del rio Taria, $12 \mathrm{~km}$ al norte de Salom, El Amparo, $10^{\circ} 15^{\prime} \mathrm{N}, 68^{\circ} 29^{\prime} \mathrm{W}, 1050$ m, 7 December 1980 (sterile), Steyermark and Carreño Espinoza 123788 (SEL).

Ornithidium elianae is very similar to $O$. pendulum and $O$. sillarense but is distinguished by its more elongate pseudobulbs, and its thinner, narrower leaves and sheath blades, 0.5$1.6(-2.3) \mathrm{cm}$ wide (vs. $2.2-4.5 \mathrm{~cm}$ wide) that are shed upon maturation of the pseudobulb (vs. thicker, relatively wider, and persistent in $O$. pendulum and $O$. sillarense). The flowers of $O$. elianae are produced a few at a time per growth (vs. O.pendulum and O. sillarense, that can produce several to many flowers simultaneously), and each flower has a straight, concave, and smooth labellum midlobe (vs. reflexed, convex, and verrucose in $O$. pendulum).

Ornithidium elianae could potentially be confused also with $O$. histrionicum Rchb.f. (synonyms: Maxillaria histrionica (Rchb.f.) L. O. Williams and $M$. aristeguietae Foldats), which also has long rhizome segments separating the narrowly ovate pseudobulbs, and small, greenish flowers (Dunsterville and Garay, 1976, 1979; Romero and Carnevali, 2000). However, the leaves of $O$. histrionicum are generally much shorter, narrower, and more rigid, the flowers are slightly larger and fleshier, and the labellum midlobe is markedly convex and has a prominent, subapical mucron abaxially (vs. concave and emarginate in O. elianae). Furthermore, in $O$. histrionicum pseudobulbs tend to be produced only at or near the base of the plant, and they become increasingly smaller and absent 
toward the distal part of the long branches. In contrast, O. elianae pseudobulbs of approximately equal size are always produced at the end of each sympodium. Both species occur sympatrically in some areas.

Ornithidium lasallei (Foldats) M. A. Blanco $\&$ Ojeda is very similar to O. histrionicum and thus also similar to $O$. elianae. However, the flowers are larger (sepals 20-27 mm long), and the more membranous labellum has proportionally less well-developed lateral lobes and a much longer central lobe than those of $O$. pendulum and $O$. elianae. Ornithidium lasalle $i$ appears to be restricted to the eastern part of the
Guayana area in Venezuela and western Guyana at elevations of 700-1500 m (Carnevali and Ramírez, 2003), where it is probably sympatric with $O$. elianae, which is rare in this area. Ornithidium lasallei has thicker rhizomes than $O$. elianae, which also tend to creep over the phorophyte's bark for most of its length and only eventually become pendulous, as opposed to O. pendulum and O. elianae, whose long rhizomes become pendent early in the development of the plant.

Herbarium specimens of Ornithidium elianae have commonly been misidentified as Maxillaria tafallae or M. ramosa.

\section{Literature Cited}

Ames, O. 1944. Destruction of the Schlechter herbarium by bombing. Amer. Orchid Soc. Bull. 13: 105106.

Atwood, J. T. 1993. A revision of the Maxillaria neglecta complex (Orchidaceae) in Mesoamerica. Lindleyana 8: 25-31.

- 1999. Maxillaria. Pages 32-84 in W. BURGER, ED., Flora Costaricensis. Fieldiana, Bot. n.s. 40. 2001. Letter to the Editor. Orchid Rev. 109: $316-317$.

- 2003a. Maxillaria. Pages 291-332 in B. E. Hammel, M. H. Grayum, C. Herrera, and N. ZAMORA, EDS., Manual de Plantas de Costa Rica. Volumen III: Monocotiledóneas (OrchidaceaeZingiberaceae). Monogr. Syst. Bot. Missouri Bot. Gard. 93.

- 2003b. Review of the Maxillaria graminifolia (Kunth) Rchb.f. (Orchidaceae) suballiance. Selbyana 24: 144-164.

Bennett, D. E., And E. A. Christenson. 1993. Maxillaria ochracea. Icon. Orchid. Peruviarum 1: pl. 110.

Bentham, G. 1881. Notes on Orchideae. J. Linn. Soc., Bot. 18: 281-360.

Blanco, M. A., G. Carnevali, W. M. Whitten, R. B. Singer, S. Koehler, N. H. Williams, I. OJedA, K. M. Neubig, And L. Endara. 2007. Generic realignments in Maxillariinae (Orchidaceae). Lankesteriana 7: 515-537.

Boggan, J., V. Funk, C. L. Kelloff, M. Hoff, G. CREMERS, AND C. FeuIllet. 1997. Checklist of the Plants of the Guianas (Guyana, Surinam, French Guiana). 2nd ed. Biological Diversity of the Guianas Program, Smithsonian Institution, Washington, D.C.

BRIEGER, F. G. 1977. On the Maxillariinae (Orchidaceae) with sepaline spur. Bot. Jahrb. Syst. 97: 548-574.
Brieger, F. G., And P. F. Hunt. 1969. Hormidium, Maxillaria, and Scaphyglottis. Taxon 18: 601-603.

CARnevali, G., AND I. M. RamíREZ-Morillo. 2003. Maxillaria. Pages 426-454 in G. CARneVali, I. M. RAmíreZ-MorILlo, AND G.A. RoMERO-GonZÁLEZ, EDS., Orchidaceae. Fl. Venez. Guayana 7.

ChIRON, G., AND R. Bellone. 2005. Les orchidées de Guyane Française. Tropicalia, Voreppe; AFCEV, Villers-Les-Nancy.

Christenson, E. A. 2002a. Maxillaria, an overview. Pages 279-290 in J. Clark, W. Elliott, G. Tingley, AND J. BIRo, EDS., Proceedings of the 16th World Orchid Conference. The Vancouver Orchid Society, Vancouver.

_. 2002b. Vue d'ensemble du genre Maxillaria. Richardiana 2: 41-62.

Cogniaux, C. A. 1904. Orchidaceae. Fl. Bras. (Martius) 3(6): 1-202.

Cremers, G., AND M. HoFf. 1992. Inventaire Taxonomique des Plantes de la Guyane Française II-Les Orchidacees. Colection Patrimoines Naturels 7. Museum National D'Histoire Naturelle, Paris.

Dix, M. A., AND M. W. Dix. 2000. Orchids of Guatemala-A revised annotated checklist. Monogr. Syst. Bot. Missouri Bot. Gard. 78.

Dodson, C. H. 2002. Native Ecuadorian Orchids, Vol. 3: Lepanthopsis-Oliveriana. Imprenta Mariscal, Quito.

Dodson, C. H., AND P. M. Dodson. 1980. Maxillaria ramosa. Icon. Pl. Trop. 2: pl. 161.

Dodson, C. H., AND A. H. GENTRY. 1978. Flora of the Rio Palenque Science Center. Selbyana 4: 1-628.

DRESSLER, R. L. 1960. Nomenclatural notes on the Orchidaceae I. Taxon 9: 213-214.

Dunsterville, G. C. K., AND E. Dunsterville. 1967. The flowering seasons of some Venezuelan orchids. Amer. Orchid Soc. Bull. 36: 790-797. 
1969. Orchids of Caracas. Amer. Orchid Soc. Bull. 38: 493-496.

Dunsterville, G. C. K., And L. A. Garay. 1959. Venezuelan Orchids Illustrated. Vol. 1. Andre Deutsch, London.

1976. Venezuelan Orchids Illustrated. Vol. 6. Andre Deutsch, London.

- 1979. Orchids of Venezuela. An Illustrated Field Guide. Botanical Museum of Harvard University, Cambridge.

Estrella, E. 1991. La expedición de Juan Tafalla y la Flora Huayaquilensis. Pages $11-42$ in I. C. Cevallos, ED., Flora Huayaquilensis-La expedición botánica de Juan Tafalla a la Real Audiencia de Quito, 1799-1808. Abya-Yala, Quito.

_ 1995. La "Flora Huayaquilensis" de Juan Tafalla. $2^{\text {da }}$ ed. Banco del Progreso-Jardín Botánico de Guayaquil, Guayaquil.

FERnÁnDEZ, C. 2004. Orquídeas Nativas del Táchira. Lotería del Táchira, San Cristóbal, Táchira.

FoldATs, E. 1970. Orchidaceae. Cuarta parte. Pages 1-558 in T. LASSER, ED., Fl. Venez. 15(4).

Funk, V., T. Hollowell, P. Berry, C. Kelloff, AND S. N. AleXANDER. 2007. Checklist of the plants of the Guiana Shield (Venezuela: Amazonas, Bolivar, Delta Amacuro; Guyana, Surinam, French Guiana). Contr. U.S. Natl. Herb. 55: 1-584.

Garay, L. A. 1967. Studies in American orchids VI. Bot. Mus. Leafl. 21: 249-264.

- 1968. Studies in American orchids VII. Caldasia 10: 231-238.

-1997. De nominibus orchidacearum incunabulorum. Harvard Pap. Bot. 2(1): 47-54.

GARAY, L. A., AND H. R. SwEET. 1972. Notes on West Indian orchids. J. Arnold Arbor. 53: 515-530.

Govaerts, R., M. A. CAMPacci, D. Holland Baptista, P. Cribb, A. George, K. Kreuz, And J. Wood. 2005. World Checklist of Orchidaceae. The Board of Trustees of the Royal Botanic Gardens, Kew; http://www.kew.org/wcsp/monocots/ (accessed 10 January 2007, 20:00 GMT).

Hamer, F. 1983. Maxillaria ramosa. Icon. Pl. Trop. Part 3. (Orchids of Nicaragua) 9: pl. 865.

1990. Orchids of Central America, an illustrated field guide (M-Z). Selbyana 11(Suppl.): $423-860$.

2001. Orchidaceae. Pages 1612-1860 in W. D. Stevens, C. UlloA, A. Pool, And M. Montiel, EDS., Flora de Nicaragua. Monogr. Syst. Bot. Missouri Bot. Gard. 85.

Hoenne, F. C. 1953. Orchidaceas, gêneros. Pages 115-147 in F. C. Hoenne, ED., Flora Brasílica 12(7), Fasc. 10. Instituto de Botânica, São Paulo.

McIllmurray, M., AND H. OAKElEY. 2001. Maxillaria platypetala Ruiz \& Pav., the type for the genus. Orchid Rev. 109: 49-51.
2004. Definizione del tipo di Maxillaria ramosa Ruiz \& Pavon./Typification of the name Maxillaria ramosa Ruiz \& Pavon. Caesiana 23: 33-41.

McNeill, J., F. R. Barrie, H. M. Burdet, V. Demoulin, D. L. Hawksworth, K. Marhold, D. H. Nicholson, J. Prado, P. C. Silva, J. E. Skog, J. H. Wiersema, AND N. J. Turland. 2006. International Code of Botanical Nomenclature (Vienna Code). Reg. Veg. 146. Available online at: http://ibot.sav.sk/icbn/main.htm.

Miller, D., AND R. WARREN. 1994. Orchids of the High Mountain Atlantic Rain Forest in Southeastern Brazil. Salamandra Editora, Rio de Janeiro.

-. 1996. Orquídeas do Alto da Serra. Salamandra Editora, Rio de Janeiro.

Miller, D., R. Warren, I. M. Miller, And H. SEEHAWER. 2007. Serra dos Orgãos-suas histórias e suas orquídeas. Editora Scart, Nova Friburgo.

ORTIZ, P. 1988. Introducción al género Maxillaria. Orquideología 17: 232-241.

-1995. Orquídeas de Colombia. 2nd ed. IndoAmerican Press, Bogotá.

PABST, G. F. J. 1972. Noticias orquidologicas: 12. Bradea 1: 173-176.

PABST, G. F. J., AND F. Dungs. 1977. Orchidaceae Brasilienses. Band II. Brücke-Verlag Kurt Schmersow, Hildesheim.

Poeprig, E. F., AND S. L. ENDLICHER. 1836. Scaphyglottis pendula. Nov. Gen. Sp. Pl. 1: 58, t. 98.

Reichenbach, H. G. 1854. Die Wagener'schen Orchideen. Bonplandia 2: 9-26.

1856. Orchideae Ruizianae et Pavonianae Musaei Boissieriani, describuntur auctore. Bonplandia 4: 210-217.

Romero, G. A., And G. CARnevali. 2000. Orchids of Venezuela. An Illustrated Field Guide. 2nd ed. Armitano Editores, Caracas.

RuIz, H. 1940. Travels of Ruiz, Pavón, and Dombey in Peru and Chile. Field Mus. Nat. Hist., Bot. Ser. 21.

- 1998. The Journals of Hipólito Ruiz, Spanish Botanist in Peru and Chile 1777-1788. Timber Press, Portland.

Schlechter, R. 1920. Die Orchideenfloren der südamerikanischen Kordillerenstaaten. II. Colombia. Repert. Spec. Nov. Regni Veg. Beih. 7: 1-301.

SchweInfurth, C. 1945. Some Peruvian maxillarias. Bot. Mus. Leafl. 11: 261-296.

Senghas, K. 1993. Subtribus Maxillariinae. Pages 1727-1803 in F. G. BRIEGER, R. MAATSCH, AND K. SEnGHAS, EDS., Rudolf Schlechter, Die Orchideen. 3rd ed. Teil 1/B. Blackwell Wissenschafts-Verlag, Berlin. 
Sitko, M., P. TukaŁŁo, and M. Górniak. 2006. Introduction to the phylogenetic analysis of Maxillaria Ruiz \& Pav. (Maxillariinae, Orchidaceae). Biodiv. Res. Conserv. 3-4: 200-204.

Sprunger, S., P. Cribb, And A. Toscano de Brito. 1996. João Barbosa Rodrigues' Iconographie des Orchidées du Brésil. Friedrich Reinhardt Verlag, Basel.

Stafleu, F. A., AND R. S. Cowan. 1988. Taxonomic Literature: a selective guide to botanical publications and collections with dates, commentaries and types. 2nd ed. Vol. VII: W-Z. Reg. Veg. 116.
Vegter, I. H. 1988. Index Herbariorum. Part II(7), Collectors T t/m Z. Reg. Veg. 117.

Whitten, W. M., M. A. Blanco, N. H. Williams, S. Koehler, G. Carnevali, R. B. Singer, L. Endara, AND K. M. Neubig. 2007. Molecular phylogenetics of Maxillaria and related genera (Orchidaceae: Cymbidieae) based on combined molecular data sets. Amer. J. Bot. 94: 1869-1889.

WitTMACK, L. 1903. Hermann Wendland (†). Gartenflora 52: 122-127. 